\title{
DIAGNOSTIC INVESTIGATION OF DECAYING LIMESTONE IN HISTORICAL BUILDINGS AT THE MAMLUKS CEMETERY- CITY OF THE DEAD, EGYPT
}

\author{
Abdelmegeed, M. ${ }^{1{ }^{(*)}} \&$ Hassan, S. $^{2}$ \\ ${ }^{I}$ Conservation dept., Faculty of Archaeology, Fayoum Univ., Fayoum, Egypt \\ ${ }^{2}$ Scientific Center for Restoration and Conservation, Ministry of Antiquities, Cairo, Egypt \\ E-mail: mmm04@fayoum.edu.eg
}

\begin{abstract}
The Mamluks cemetery, City of the dead, is one of the famous historical Islamic places that contain many outstanding structures. Limestone, which is the main building material used in the Mamluks cemetery buildings, always underwent weathering processes and deterioration factors. The present study is an analytical and petrographic assessment of limestone used in historical buildings in Cairo-Egypt. It is organized into three main sections. The first section provides a historical background of Mamluks cemetery. The second one sets out to evaluate the current situation of the decaying limestone. The third section explains the alteration mechanisms between deterioration forms and surrounding environmental factors. Visual, microscopic, and laboratory analysis by means of PM, XRD, and EDX highlighted the causes of limestone decaying. The decay phenomena of limestone in the (City of the dead) are independent of the exposure of the architectural surface and are strongly influenced by the sedimentary nature (micro laminations), which acts with the formation and distribution of salts as preferential planes for the formation of aggressive weathering forms. Another issue is related to the formation of cavities. Furthermore, small quartz grains occasionally occupy some shell cavities (chambers).
\end{abstract}

Keywords: Building materials, Salt crystallization, Damage phenomena; Petrographic characteristics, Thin-section, EDX

\section{Introduction}

Limestone is conspicuously one of the oldest and very common building materials, especially in Egypt. Its use as dimension stones for buildings in Egypt dates back to early antiquity. It was a prevalent building block in the middle Ages because it was hard, durable, and easily accessible at surface exposures. Many landmarks buildings across the world, including the Egyptian pyramids, are built of limestone [1-4]. In the Islamic civilization, particularly in Cairo, limestone is largely used in historic buildings not only in the form of dressed stones but also in the form of undressed rubble stones. However, smooth square or rec- tangular stones are used in the ashlar masonry construction techniques that require stones of the same height within each course, but each course can vary in height [4-6]. Egyptian limestone has many properties, such as the widespread availability, color varieties, and distributions, as well as easy processes to form, write, and draw on it. These properties have helped Muslim constructors to use limestone in the construction of buildings in the Mamluks cemetery. In addition to basic tombs and mausoleums, the Mamluks cemetery contains many impressive Islamic structures, such as mosques, splendid domed tombs, and other religious and funerary buildings, 
especially from the Mamluk period (12501570 A.D) [7]. Over time, all building materials, especially limestone, have been affected by many deterioration factors such as weathering processes, groundwater, and air pollution. Weathering, as a general term, is applied to all mechanisms of alteration of building materials [8-10]. On one hand, there have been several reviews on damage mechanisms of limestone recently concerning the identifying of damage mechanisms, phenomena, and influencing factors, especially salt weathering processes $[8,10-13]$. On the other hand, the textural and petrographical characteristics of limestone have been discussed by several works [10,13-
17]. The present study describes the preliminary stages of preservation to decaying limestone in the Mamluks cemetery's buildings in Egypt. Therefore, it is concerned with microstructural and compositional characteristics of limestone along with the relationship to the decay patterns discussed. It comprises the application of several investigation methods. Historical and structural description, visual observation, sampling of building materials, and laboratory testing of the samples are the main steps of the investigation and assessment of the limestone used in Sultan Qaytbay mosque (879 AH / 1474 AD). Furthermore, the study detects the mechanisms of limestone deterioration.

\subsection{General description of the study area}

Historically, Cairo is the city with the largest cluster of heritage architecture worldwide. It isn't simply the largest in the number of monuments to the glorious era, but also the weight of their architectural, artistic, and historic value, as well as their various functions $[6,7,10,18,19]$. Historic Cairo was cited as covering an area of around 35 square kilometers (eastern direction of the Nile River and the foot of the Mokattam Mountain). The Mamluks cemetery is one of the oldest regions of Mamluks' remains located at the feet of Mohamed Ali Citadel and Mokattam's rock. It was built on the northern side of the ancient town of Fatimid Cairo. It is a widely famous Islamic necropolis and cemetery below the Mokattam hills. Moreover, the Cairenes and most Egyptians call it el'arafa (the cemetery). It is 4 miles $(6.4 \mathrm{~km})$ long (north-south) dense grid of tomb and mausoleum structures. The area is rich in important religious archeological structures, including tombs, mosques, and other burial structures. Over the last few decades, an intense residential densification process of the urban fabric occurred and combined with the physical degradation of several monuments and burial structures in the Mamluks cemetery [20]. Most of the tombs and ancient extensive cemeteries have been occupied by squatters, some of whom live in the tombs themselves, while others live in self-built constructions between and around the tombs, fig. (1) [7,19]
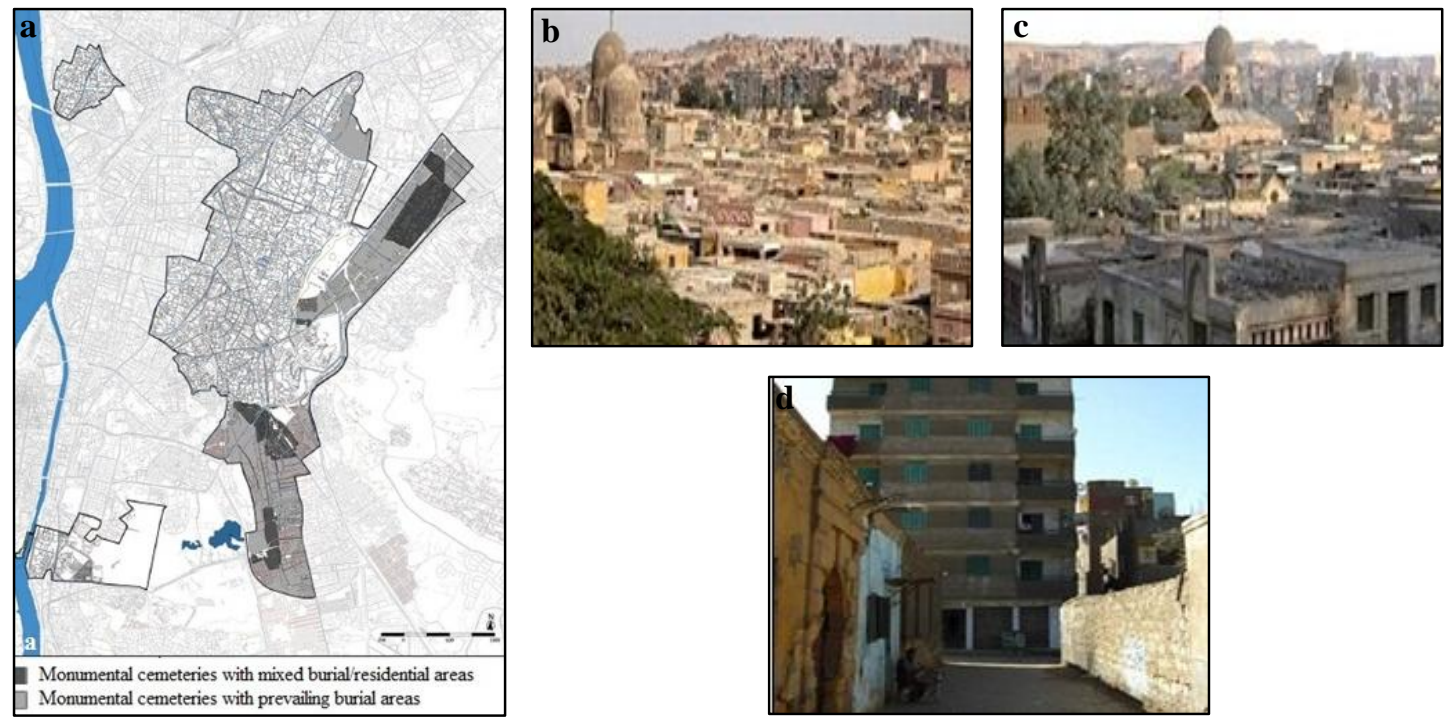

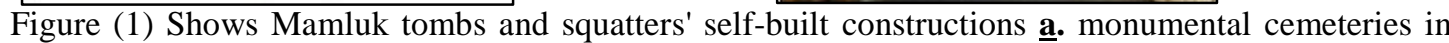

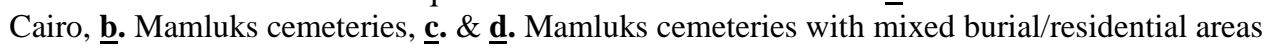




\subsection{Sultan Qaytbay mosque}

Sultan Qaytbay mosque is a famous historical building located at the northern Mamluks cemetery. Sultan al-Ashraf Abu al-Nasr Qaytbay built his mosque in 879 $\mathrm{H} / 1474 \mathrm{AD}$, fig. (2). The entrance of the mosque, as most of Mamluks' buildings, is located in the north. It typically follows the Mamluk entrances style, commonly crowned with a tri-lobed arch and decorated with carved stalactites (muqarnas). Sultan Qaytbay complex contains three architectural units: The mosque, madrasa (religious school), and sabil (the charitable dispensation of water) located to the left of the mosque's entrance. The minaret of the mosque is located on the lefthand side of the entrance. It is considered one of the most complete Mamluk minaret examples, representing both the architectural compatibility and the decorative skills of the Mamluk era. Moreover, Qaytbay mosque is a one-storey masonry building; the multiple bearing walls forming the structural system of the mosque, fig. (2), which also shows the general structural system of the mosque complex (the mosque, madrasa, and sabil). The façade of the building lies on Qaytbay Street and has a length of $19 \mathrm{~m}$, and its left-hand side façade lies on the same street with a length of $45 \mathrm{~m}$, whereas its righthand side façade is on a small street (Zokak). Wall 4 essentially forms the fence and separates the building from the adjacent property. Additionally, the structural walls of the mosque are $0.9-1 \mathrm{~m}$ wide. They were built with chiseled/

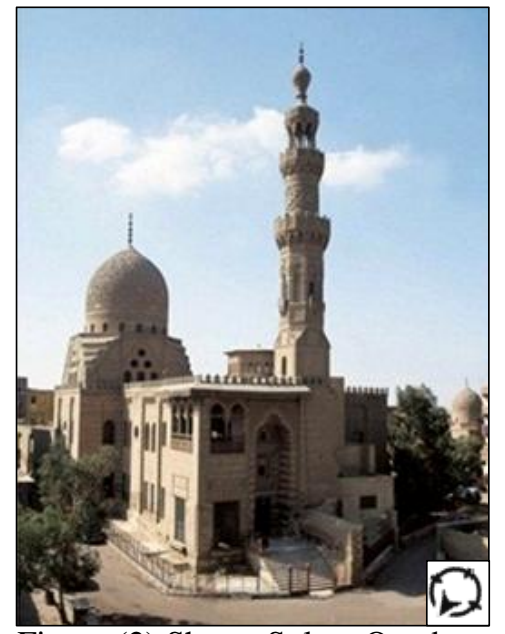

Figure (2) Shows Sultan Qaytbay mosque (879 AH / 1474 AD) smooth limestone, bound together with mortar. More specifically, the materials used for constructing the masonry walls are, as follows: *) Limestone - chiseled or smooth stones used in the two faces of the double bearing walls, and not iregularly-shaped stones. *) Mortar (binding material) - lime mortar is one of the most mortar types used in the construction of most Islamic buildings in Cairo. Moreover, they mixed lime with Homra (red/fired brick powder) to give lime some mechanical and physical prosperity [21]. The ground plan of the madrasa consists of a square courtyard with a polychrome marble floor and a ceiling with a central skylight. The nave is surrounded by four Iwans (arcades). The biggest is Kiblah Iwan, which overlooks the nave utilizing a horseshoe arch and includes a magnificent Minbar (the tribune) decorated with intricate geometric ornamentations. The mosque has a unique Mamluk dome style. The transition zone from a square to the circularity of the dome consists of nine tiers of intricately detailed stone (muqarnas). The dome is decorated with ornaments of carved stone. In our case, limestone shows severe patterns of decaying that notably affect the aesthetic and historic appearance of the mosque. Climatic factors, groundwater, human activities, and air pollution are the man causes of these changes and/or alterations, e.g. salt efflorescence, exfoliation, bleeding, irregular material loss, bio-deterioration, and black crust.

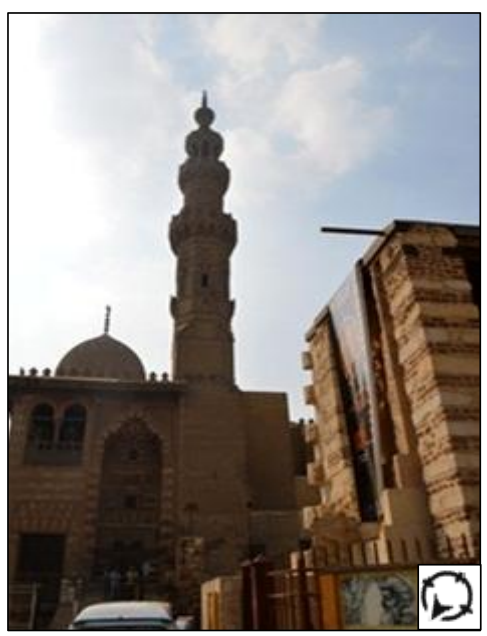




\section{Materials and Methods}

Based on the methodology concerned with the analytical and petrographic assessment of weathering limestone used in Sultan Qaytbay mosque which is considered to represent the stone weathering processes in historical buildings in Mamluks cemetery. In this mosque; limestone has suffered significant weathering actions due to various causes, especially the hard attack of environmental factors and manmade actions. Studies on the diagnosis of decaying limestone were carried out using both non-destructive and destructive methods. While the non-destructive methods

\subsection{Direct observation}

Direct observation of the structure is a primary and essential phase of the building material assessment processes, usually carried out by highly skilled and experienced conservators to provide an initial understanding of the structure and to give an appropriate direction to the subsequent investigations. The main objectives include identifying deterioration phenomena, damage maps, and any ongoing environmental effects on the building [3, 22,23]. According to the guidance methods in the architectural field [6], the Architectural structure and surrounding area of Qaytbay Mosque have been studied by close inspection and complimentary survey (CICS) or employing the description of the current state. CICS is a simple method to search for evidence of different include photographic recording and direct observation, the destructive methods are Polarizing Microscope (PM), Energy Dispersive X-Ray Spectroscopy (EDX/EDAXOxford-2.135, $11.408 \mathrm{keV}$ ), and X-Ray Diffraction (Panalytical X, pert pro PW 3040/60). These methods were used to investigate all intrinsic and extrinsic factors affecting the building materials to define their deterioration mechanisms and pathologies in the course of the Mosque life.

past activities that happened in the Qaytbay mosque area. It could be achieved through direct observation of the outer part of the mosque walls and studying the environmental, social, economic activities, as well as community facilities of the wider area. CICS of Qaytbay Mosque area shows that continuing deterioration of historic structures due to the misuse of residents, lack of public investment, regular upkeep of city infrastructures, absence of essential community facilities and services, and hard attack of the surrounding environmental factors (groundwater, humidity...etc.) $[7,20,24]$. The results indicate that there are various damage phenomena, such as cracks patterns, stone bleeding, salts crystallization, and damping, fig. (3).
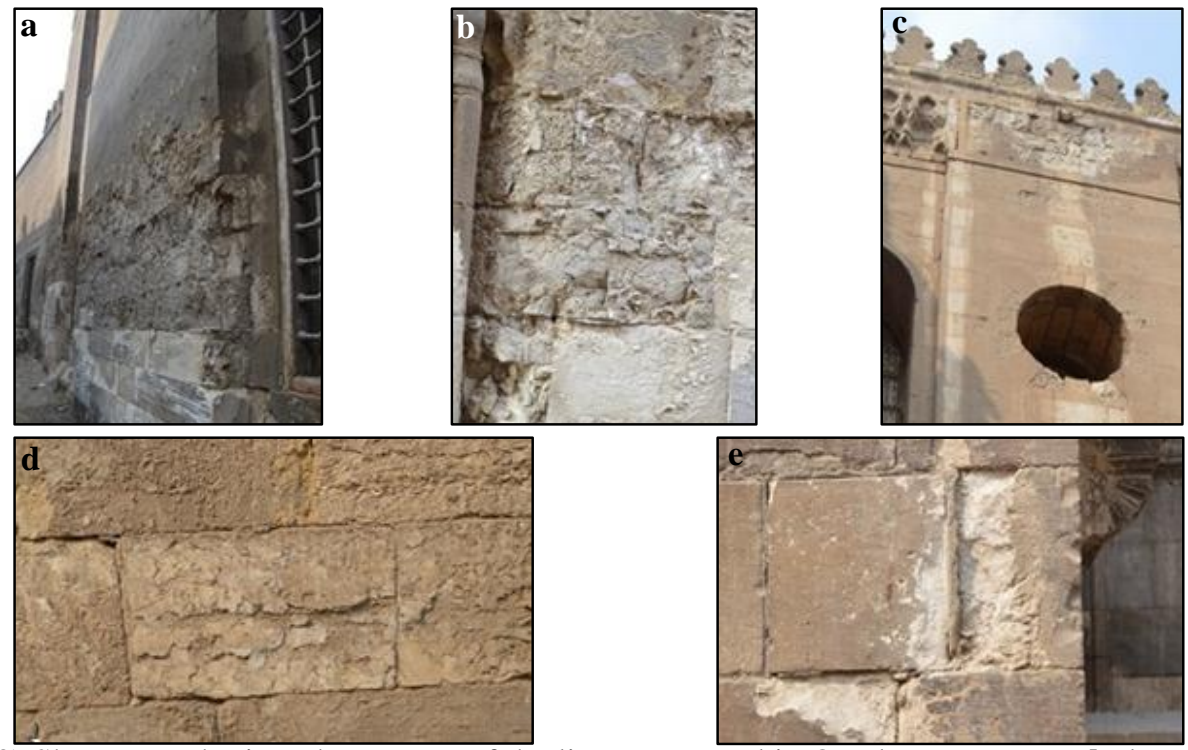

Figure (3) Shows weathering phenomena of the limestone used in Qaytbay mosque $\underline{\mathbf{a}} \cdot \underline{\mathbf{b}}$. lower parts, $\underline{\mathbf{c}}$. upper parts, $\underline{\mathbf{d}}$. and $\underline{\mathbf{e}}$. middle parts of the mosque walls 


\subsection{Damage Identification (diagnosis)}

Islamic heritage buildings in Mamluks cemetery are continually prone to many serious damage factors, as shown in the building materials' damage phenomena [20, 21]. Over time, all these natural stones, especially limestone, have been badly affected by several weathering factors. The interaction between limestone and natural or anthropogenic weathering factors control the type and extent of decay phenomena $[10,11,17]$. Weathering is applied to all mechanisms of alteration of building materials. It can be classified according to its origin, as follows: *) chemical weathering; concerning the stone solubility or reactivity with other factors of deterioration, such as air pollutants $[17,25$, 26] and *) physical weathering; concerning

\subsection{Sampling}

Many limestone samples were collected from the main building material used in the mosque, fig. (4). They included eight limestone samples inside and outside, as the stone resistance to expansive stress within the pore structure, e.g. salt crystallization [27]. Both kinds of weathering cause many deterioration phenomena affecting the stone used in historical buildings [10,28-30]. As shown in fig. 3, decaying forms in limestone are closely related to weathering factors either exogenous or endogenous. Both close inspection and complimentary survey (CICS) and damage identifications illustrate that decaying limestone in Qaytbay Mosque has been affected by several deterioration factors, e.g. air pollution, and different sources of moisture, especially sewage enriched with different kinds of salts.

well as upper and lower partitions of the building. They were obtained by carefully removing relatively small stones using a chisel or by falling stones.

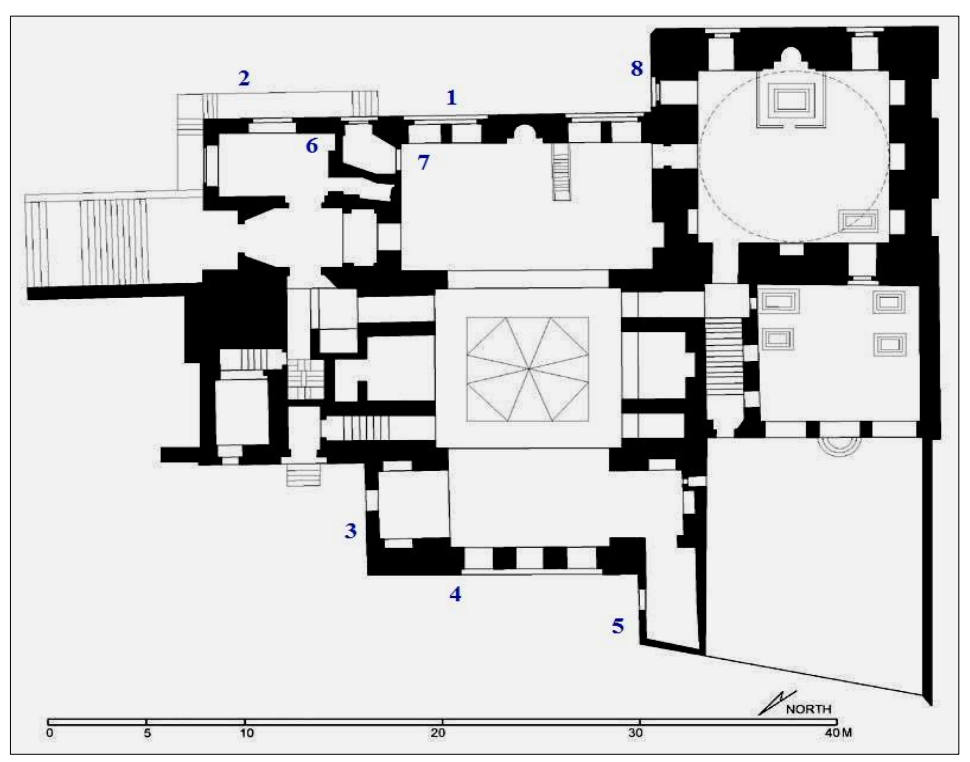

Figure (4) Shows the location of sampling inside and outside the building

\subsection{Investigation and analysis methods}

The collected samples were analyzed and studied to identify the different weathering forms, products, such as salt profiles and salt types, and state affecting limestone in Qaytbay mosque. The analyses were divided into two methods, the first one is non-destructive and destructive, and the second is destructive methods. The non-destructive methods included photographic recording and direct observation to record the current situation of limestone, the destructive methods were used to evaluate the components and the deterioration phenomena in limestone. PM (Zeiss Axio Imager) was used under both the plane-polarized light (PL) and crossed polars/Nichols $(\mathrm{CN})$ for defining the optical and mineralogical characteristics of the 
samples. EDX-Oxford with JSM 5300 Scanning electron microscope at aceleration voltages of $10-30 \mathrm{kV}$ was used for investigating the morphological features of the samples. Moreover, the EDX technique was adapted for analyzing their main elemental components. Finally, the mineralogical characteristics and compositions of the alteration phases were iden-

\section{Results}

\subsection{Thin-section test results}

Based on the classification of Dunham,1962 [15], the petrographical characteristics of the samples were identified as carbonates (samples no. 1,4,5,7, and 8 ), and carbonatic fragments (samples no. 2,3, and 6). The carbonate samples contained micrite matrix crowded with minute foraminiferal tests with a coarser shell that partly re-crystallized as micro sparry calcite, fig. (5). Microscopically, the samples are large foraminiferal (nummulitic/packstone), and they are composed of skeletal allochems of different sizes and shapes, along with some scatted quartz
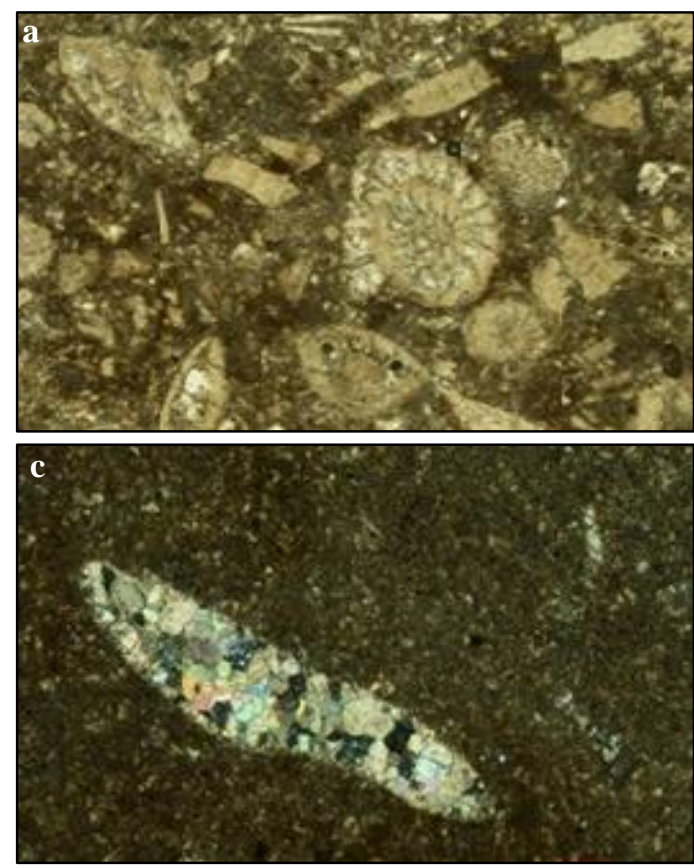

tified by X-Ray Diffraction (XRD) analysis by a Panalytical $\mathrm{X}$, pert pro PW 3040/60, X-Ray Diffractometer, with nickel-filtered $\mathrm{Cu}$ radiation $(\lambda=1.540 \AA$, $45 \mathrm{kV}$ and $40 \mathrm{~mA})$. The result phases were also identified using the Inorganic Crystal Structure Database (ICSD) chosen for the best correlation.

grains (sample no. 1). Some samples showed carbonate cuttings. Each of them was bioclastic lime-mudstone to wackestone. These rock cuttings were dark gray to reddish dark gray and brownish to reddish. They are relatively hard carbonate rock (packstone/wackestone). However, (samples no. 2,3, and 6) under crossed Nicols showed that they were iron-stained rock salt, mainly of halite composition (Nacl), including rock particles of fossiliferous limestone (carbonate fragments).
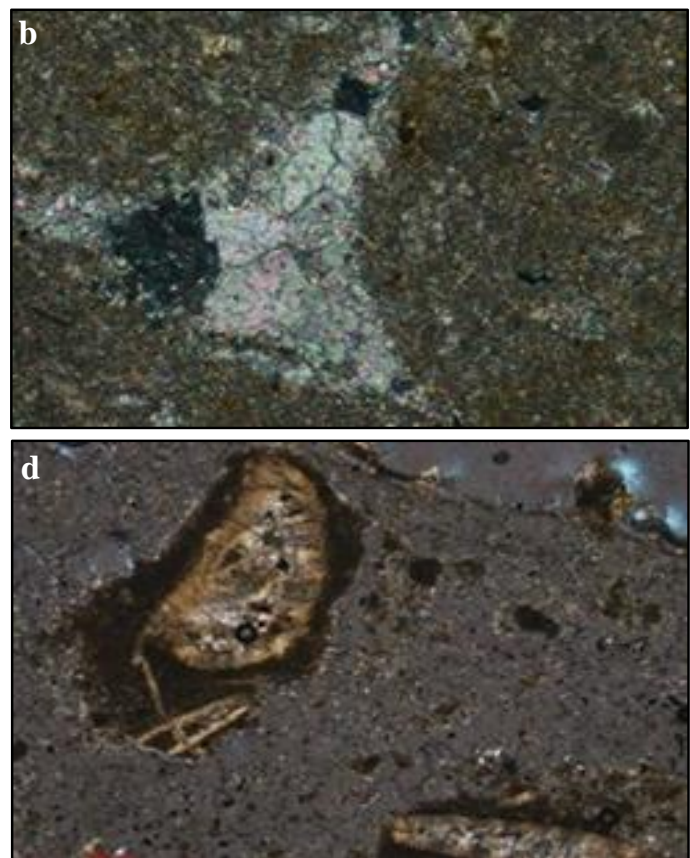

Figure (5) Shows thin section photomicrographs for samples $(1,5,6,2)$, where, $\underline{\text { a. }}$ under plane-polarized light (PL), and $\underline{\mathbf{b}}$., $\underline{\mathbf{c}}$. and $\underline{\mathbf{d}}$. under crossed polars/Nichols $(\mathrm{CN})$

\subsection{SEM-EDX test results}

SEM captures fig $(6-a \&$ b) indicate that limestone samples had wide ranges of deterioration and fault features. The deterioration features included cavities, micro-cracks, small fissures, smoothing in the outer surface of calcite grains, eroded pits, and salt crystals, such as halite $[10,12,26]$. Halite crystals existed 
as a major salt because it is the predominant salt species in the Egyptian soil. Moreover, Micro-cracks and cavities resulted from the textural characteristics of sedimentary rocks and the effect of deterioration processes. EDX results, tab. (2) and fig. (6-c \& d) there showed differences
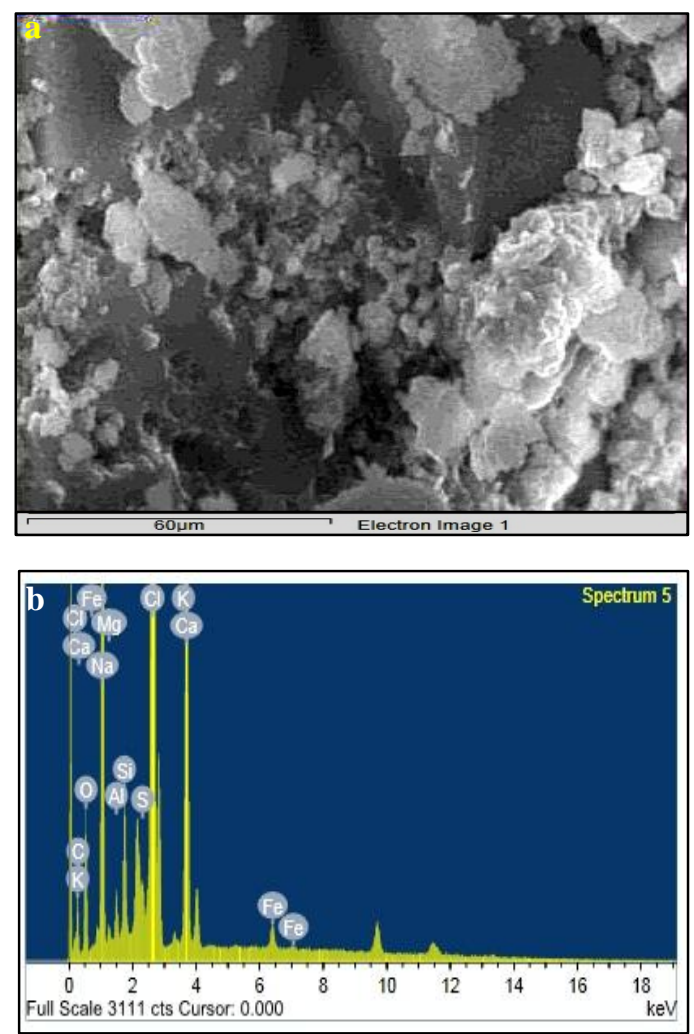

Figure (6) Shows SEM photomicrrograohs and EDX pattern of invesetigated samples $\underline{\mathbf{a}} \cdot$ \& $\underline{\mathbf{b}}$. sample 1, c. \& d. sample 2

\subsection{XRD test results}

The mineralogical compositions of the investigated samples using the XRD technique showed that they are composed of three phases of minerals, namely major, in the elemental ratios that are responsible for deterioration forms $(\mathrm{Cl}, \mathrm{Ca}, \mathrm{Na}, \mathrm{O}$, and $\mathrm{C}$ ). Such elements indicated the different deterioration mechanisms affecting the limestone as a result of different deterioration factors dominating the area of study.
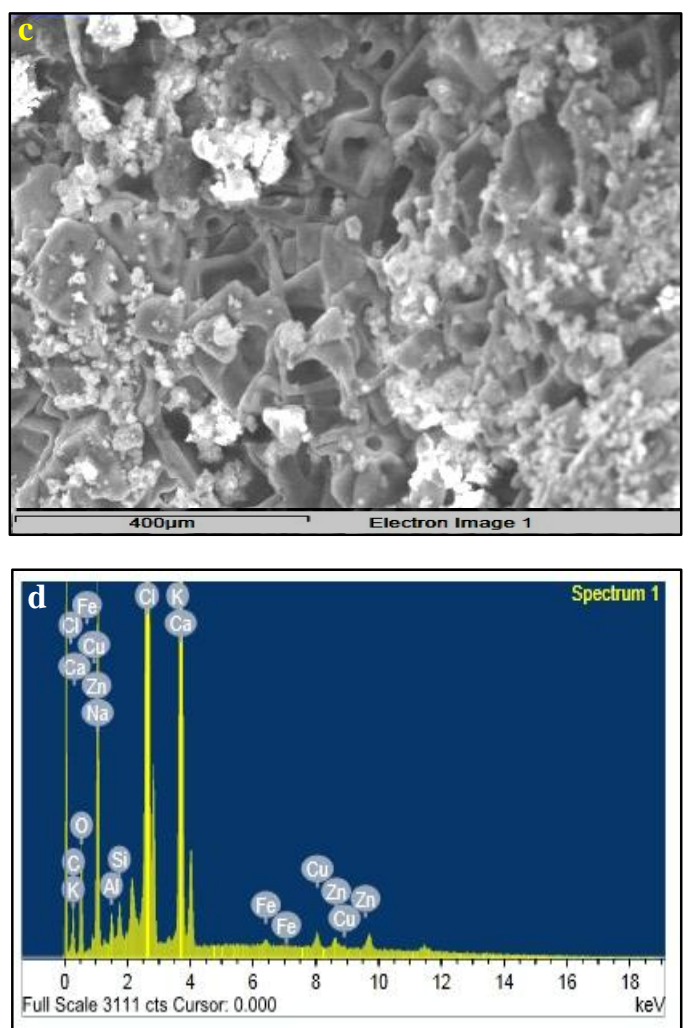

Table (1) The mineralogical compositions of stone samples

\begin{tabular}{|c|c|c|c|c|c|}
\hline \multirow[b]{2}{*}{ Sample } & \multirow[b]{2}{*}{ Sample place } & \multirow[b]{2}{*}{$\begin{array}{c}\text { Samples } \\
\text { description }\end{array}$} & \multicolumn{3}{|c|}{ Analytical Results } \\
\hline & & & $\begin{array}{l}\text { Major } \\
\text { minerals }\end{array}$ & $\begin{array}{l}\text { Minor } \\
\text { minerals }\end{array}$ & $\begin{array}{c}\text { Trace } \\
\text { minerals }\end{array}$ \\
\hline $\mathbf{R}_{\mathbf{1}}$ & $\begin{array}{l}\text { Outside the building (the sixth course of } \\
\text { the N-W facade wall) }\end{array}$ & $\begin{array}{l}\text { Disintegrated } \\
\text { surface }\end{array}$ & $\begin{array}{c}\text { Halite } \mathrm{NaCl} \\
85 \%\end{array}$ & $\begin{array}{c}\text { Calcite } \mathrm{CaCo}_{3} \\
15 \%\end{array}$ & --- \\
\hline $\mathbf{R}_{\mathbf{2}}$ & $\begin{array}{l}\text { Outside the building, the first course, } \\
\text { close to foundations, (N-W facade wall) }\end{array}$ & $\begin{array}{c}\text { Salty and highly } \\
\text { disaggregated crust }\end{array}$ & $\begin{array}{c}\text { Halite } \mathrm{NaCl} \\
100 \%\end{array}$ & --- & --- \\
\hline $\mathbf{R}_{\mathbf{3}}$ & $\begin{array}{l}\text { Inside the building, } 6.5 \mathrm{~m} \text { high from the } \\
\text { ground level }\end{array}$ & $\begin{array}{l}\text { Deteriorated stone } \\
\text { surface }\end{array}$ & $\begin{array}{c}\text { Calcite } \mathrm{CaCo}_{3} \\
96 \%\end{array}$ & --- & $\begin{array}{c}\text { Ankerite } \\
\mathrm{Ca}\left(\mathrm{Fe}_{+2} \mathrm{Mg}\right) \\
4 \%\end{array}$ \\
\hline
\end{tabular}

As indicated in table 1 the mineralogical compositions of the collected samples show the hard attack of weathering processes on the limestone used in the mosque, in particular, those collected from the lower parts of the outside walls. Otherwise, the samples collected from the higher parts of the inside walls show minimal affected with weathering processes. 

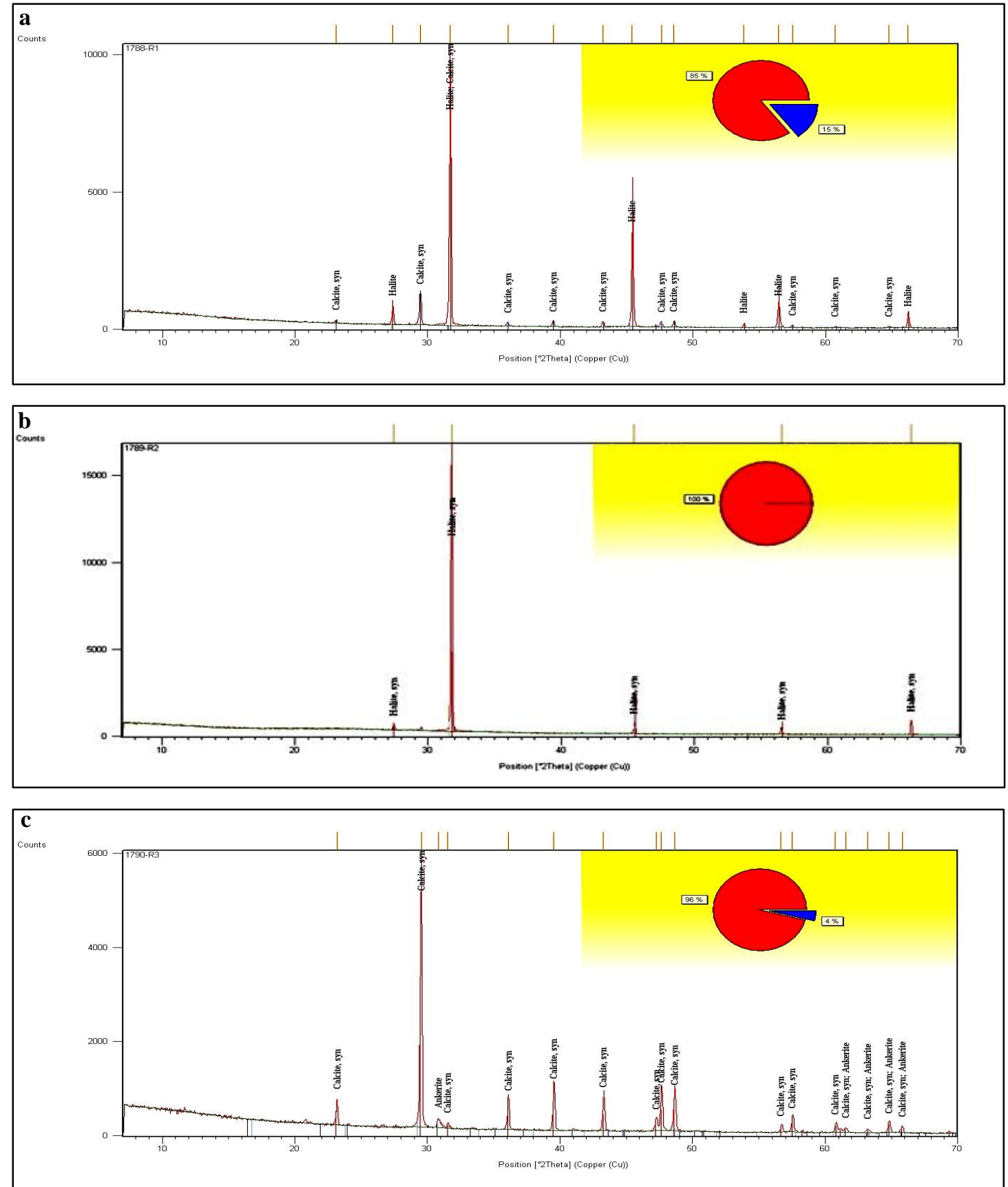

Figure (7) Shows XRD patterns of limestone a. sample R1 (card number: Halite 01-071-3741, Calcite 01-085-1108), b. sample R2 (card number: Halite 01-071-4662), c. sample R3 (card number: Calcite 01-085-0849, Ankerite 00-041-0586)

\section{Discussion}

Based on the different analyses and tests of the limestone samples of Sultan Qaytbay mosque, several decaying features affecting the physical and chemical properties of limestone could be concluded. The formation and distribution of salts on and under the limestone surface depended essentially on several variables, such as the kind and concentration of salt soluble in the groundwater, salts due to chemical reaction between the wet surface of limestone and air pollution, and salts in the stone component itself [10$12,17,26,31]$. Moreover, the hydration and the crystallization pressures are deemed as essential processes of masonry deterioration $[2,32]$. 


\subsection{Petrographic description}

The tested samples showed that the color of the limestone varies from white to dark gray and dark yellow [33]. Multicolor was caused by three factors: The sedimentary nature, the effect of the weathering process, and the soluble and suspended aerosols in the groundwater. Otherwise, limestone samples showed that, on one hand, the stone was dark gray bioclastic foraminiferal packstone consisting of micrite matrix amalgamated with minute foraminiferal tests with traces of dolomite crystals that were associated with very view coarser shells badly preserved benthic floating in a dense lime-mud or slightly dolomitized microspare matrix, which was very crowded with the minute foraminiferal tests. On the other hand, the cavities were leached fossil molds later filled by drusy sparry calcite crystals with no internal structure. However, relices of biomicrite patches are still observed. As shown in fig. (5), the stone composed of carbonate cuttings; each of them was broclastic lime-mud stone to wackestone. These stone cuttings were dark gray to reddish-gray containing iron oxide patches and micro spots within stained micrite. Occasionally, few coarse-grained $(0.7 \mathrm{~mm}$ in average diameter) of foraminiferal tests and carbonate rock fragments were scattered throughout homogenous micritic matrix that was rich in minute to small foraminiferal tests. The majority of these tests were replaced by micro-sparry calcite stained by iron oxide impregnation. The walls of the coarse-grained foraminiferal shells cavities are composed of fibrous pseud spars while the chambers themselves are mainly filled with fine calcite spare crystals or micro-sparry micrite. Some foraminiferal shells are well preserved with isopachous calcite walls, while others are present as ghosts of foraminiferal tests embedded in iron-stained mottled micrite. The thin-section test indicated that the stone is brownish to reddish and relatively hard carbonate stone. The stone is composed of slightly dolomitic micritic matrix rich in minute foramina- feral tests with moderately sorted coarse floated well preserved benthic and echinoid spines. The benthic foraminiferal tests varied in shape showing micritic envelopes and chamber walls, while their chamber lets were filled with equal sparry calcite or pseudo micrite and some shell cavities, which seemed to be residual spaces after leaching of the original coarse carbonate allochemes were completely filled with typical drusy sparite plates with no internal structure preserved elongated spine was composed of micro-fibrous calcite while its internal cavities were filled with microspary calcite. Microscopically, the stone is a large foraminiferal (Nummulitic) packstone. It was composed of skeletal allochems of different sizes and shapes, and some scattered quartz grains embedded in fine-grained micritic or pseudospar of a partially dolomitized matrix. The allochems were mainly represented by large foraminiferal tests, crinoid skeletal fragments, algal plates and other bioclasts, as shown in fig. (5). The allochems represented by large foraminiferal tests were mainly of the lower Eocene large forams e.g Nummulite sp. Operculina sp, Discocyclina sp., and other smaller tests. The original internal structure of the large and small tests of Nummulite was preserved as diagnostic calcite fibrous wall structure. This calcite was formed after the dissolution of original aragonite shell walls. The chambers of these tests were filled with granular microspars or with completely micritized material. Occasionally, small quartz grains occupied some of these champers. However, limestone had iron stained, mainly of halite $(\mathrm{NaCl})$ including particles of fossiliferous limestone (carbonate fragments). The carbonate fragments are composed of large benthonic foraminiferal tests impregnated by ferruginous carbonate materials. These tests (mainly Nummulite tests) embedded in a highly ferruginous micritic matrix. They are preserved and rimmed by isopachous fibrous calcite. The cavities or chambers were filled by 
pseudo spars or by iron-stained micrite. Occasionally, some carbonate fragments formed with their isopachous fibrous wall structure were corroded by the salt crystals cement. The thin sections indicated that the sample consisted of salt with iron stained fossiliferous carbonate fragments having different grain sizes. The fragments were associated with scattered nummulite shells and badly preserved benethic tests that embedded in iron acid stained carbonate matrix. Salt, forming the main component of the samples, is isotropic cleavable crystals showing low to moderate relief. The salt crystals possessed fluid-inclusions and showed a chevron texture. The nummulite shells were replaced and corroded by the iron oxide stained carbonate matrix. The rock salt crystals were isotropic (since cubic) showing low relief and strong rectilinear

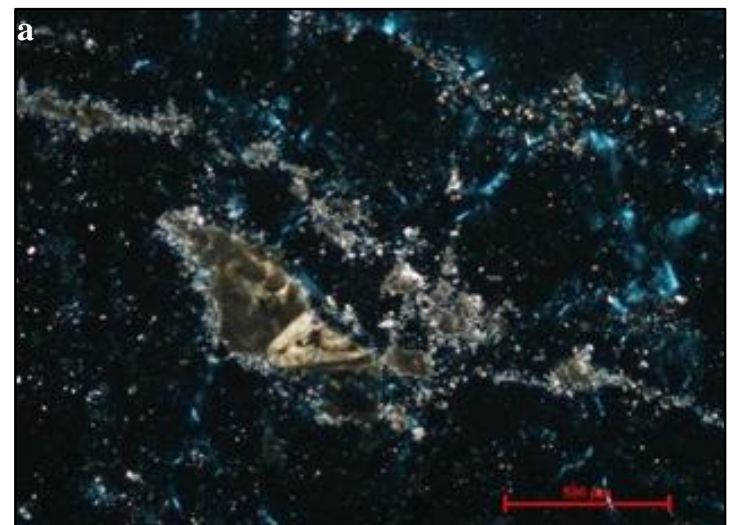

cleavage, and the fossiliferous ironcarbonate fragments were corroded by the salt crystalline material. Sample (no. 6), fig. (8), indicated that it is a stylolite crystalline salt mass containing dark carbonate fragments of fossiliferous ironstained micritic limestone. The transparent salt (of halite composition) crystals showed strong cleavage and fluid inclusions, few fibrous gypsum crystals, and other impurities. The elongated cleavage and irregular stylolite fractures, as well as voids or joints, were stained by iron oxide impregnations. Otherwise, the nummulite shell was corroded by the development of recrystallized fibrous salt. Occasionally, the salt crystals grew most rapidly, so developing a chevron texture such texture may be formed by the arrangement of the inclusions.

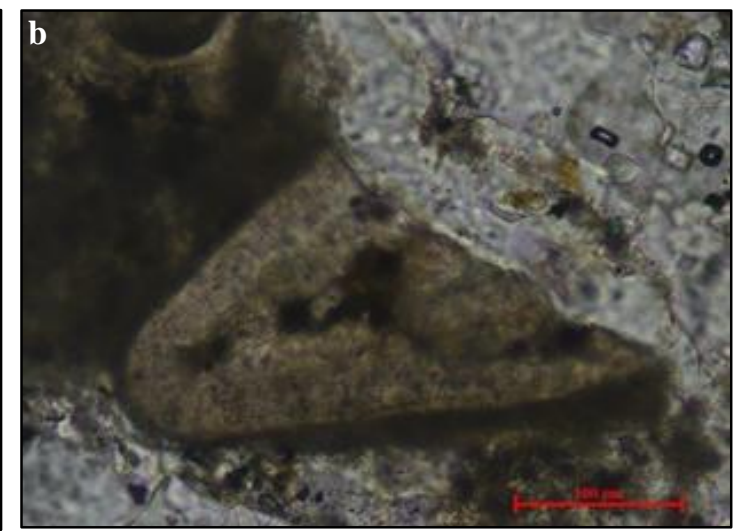

Figure (8) Shows thin section photomicrographs for sample (no. 6) ‥ . crossed polars/Nichols (CN), $\underline{\mathbf{b}}$. under plane-polarized light (PL) with stylolite crystalline salt mass containing dark carbonate fragments of fossiliferous iron-stained micritic limestone

\subsection{SEM and EDX (morphological description and chemical(composition}

SEM micrographs fig. (6-a,b) indicate that limestone samples have wide ranges of deterioration features, including cavities, micro-cracks, small fissures, smoothing of the outer surface of calcite grains, eroded pits, and salt crystals, e.g. halite $[10,12,26]$. Halite crystals existed as a major salt since it is the predominant salt species in the Egyptian soil [34]. The presence of micro-cracks and cavities resulted from the textural characteristics of sedimentary rocks and the effect of deterioration processes. Moreover, SEM micrographs illustrate that all parts of the mosque walls' have been exposed to several damage processes that caused damage products, such as salts on stone surfaces and between internal grains. The obtained results of the chemical elemental ratios by EDX, tab. (1) refer to deterioration processes affecting limestone due to chemical-physical weathering processes. These different ratios are responsible for deterioration forms $(\mathrm{Al}, \mathrm{Na}$, $\mathrm{Si}, \mathrm{S}$, and $\mathrm{Fe}$ ). Furthermore, the obtained elemental ratios are clear evidence of the different deterioration mechanisms affecting the stone surfaces that result from the surrounding deterioration factors in the Mamluks cemetery. Therefore, 
the presence of such elements in such high values is mostly ascribed to the direct effects of groundwater, dusting, aerosols, and air pollution, which are the main deterioration factors in the Mamluks Cemetery region. Moreover, the EDX test with SEM micrographs illustrates salt efflorescence ( $\mathrm{Na}, \mathrm{K}$, and $\mathrm{Cl})$ which refer to the wetting and drying cycles caused by the alternative processes between air temperature and different sources of moisture [35]. The high ratios of salts were mostly due to the direct effects of damp rising, air pollu- tion, and sewage because of the absence of infrastructure maintenance in the area. The relation of the deterioration products (i.e. $\mathrm{Cl}, \mathrm{Si}, \mathrm{Na}, \mathrm{S}$, and $\mathrm{Fe}$ ) and the essential component of limestone $(\mathrm{Ca})$ was rated 52\%:48\%, fig. (9). The high ratio of deterioration elements suggested severe deterioration factors. Furthermore, the high ratio of degradation in the lower and higher parts of Qaytbay Mosque walls (higher than 2 meters) was due to the effect of salt weathering on the building materials.

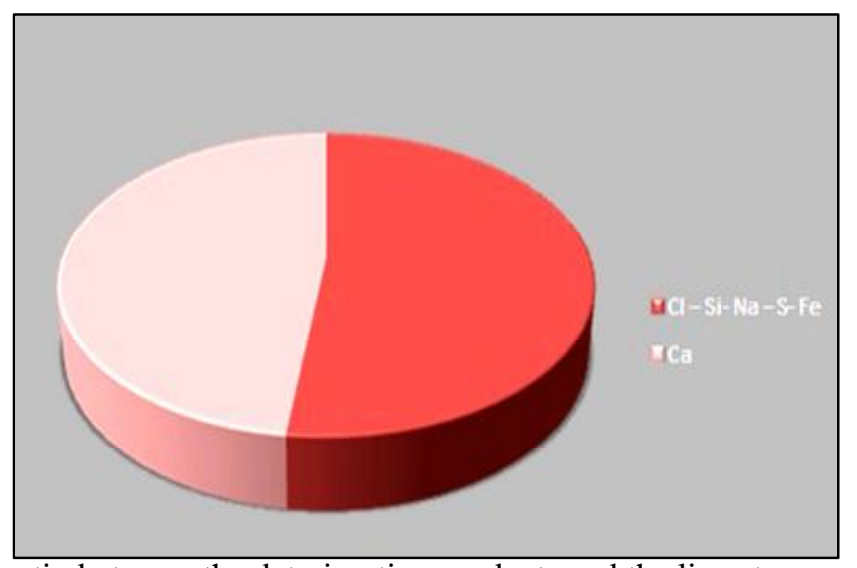

Figure (9) Shows the ratio between the deterioration products and the limestone components

\subsection{Mineralogical composition by XRD}

As indicated in tab. (2) and fig. (7-a,b,c), the XRD results showed that the weathering products affecting the limestone in the Mosque varied according to the sampling location (inside or outside the building) and height on walls. In the $1^{\text {st }}$ category (sample $\mathrm{R}_{1}$ and $\mathrm{R}_{2}$ ), the presence of halite $\mathrm{NaCl}$, as a major mineral, clarified the severe weathering processes to limestone. It often results from the chemical reaction between calcite- the main component of the limestone- and different contamination ions that in the groundwater (e.g. $\mathrm{SO}_{4}$, $\mathrm{NO}_{\mathrm{x}}$, and $\mathrm{Cl}$ ). This process particularly accelerated with alternative cycles between the air temperature and the sources of moisture (wetting and drying cycles) [36]. However, the higher value of weathering products, particularly halite was due to the combination of surrounding deterioration factors, especially groundwater, sewage, and lack infrastructure system $[10,26]$. In the $2^{\text {nd }}$ category (sample $\mathrm{R}_{3}$ ), the presence of calcite $\mathrm{CaCo}_{3}$ as a major mineral was due essentially to some sheltered areas that have not been affected by the dissolution process [37]. However, the weathering products as minor or trace minerals were because the samples are away from the effect of the weathering process. Ankerite $\left[\mathrm{Ca}\left(\mathrm{Fe}^{2+}, \mathrm{Mg}\right)\left(\mathrm{CO}_{3}\right)_{2}\right]$, it is rhombs have a dark core of iron oxide and clear outer rims [38]. It is closely related to dolomite but differs in having magnesium replaced by varying amounts of iron (II) and manganese. It is one of the minerals of the dolomite-siderite series and appears because of the weathering products resulting from the soiling and dusting mechanisms, the chemical transformation of some minerals, such as Hematite to Goethite [10], or the hydration phenomena that affect some dominated minerals in the area. 


\section{Conclusion}

The building materials in the Islamic architectures of the Mamluks Cemetery-Egypt has been prone to many deterioration factors, e.g. groundwater, air pollution, alternative actions between air pollution and different sources of moisture, intentional and unintentional human activities, and salt crystallization on or under the limestone surfaces. Limestone use in the construction of Islamic building materials dates back to the Lower Eocene. Its color varied from white to dark gray and had a lot of marine fossils, iron stains and foraminiferal (Nummulitic) packstone. Multicolor in decaying limestone used in the Mamluks Cemetery was due to three factors: The sedimentary nature, the weathering process, and the soluble and suspended aerosols in the groundwater. The decay phenomena of the Egyptian limestone (used in the Mamluks Cemetery) were independent of the exposure of the architectural surface and were strongly influenced by the sedimentary nature (micro laminations), acting with the formation and distribution of salts as preferential planes for the formation of aggressive weathering forms. There were inter-granular disintegrations of the lime-mud cement, cavities, and chambers. Occasionally, small quartz grains occupied some of these chambers and played an essential role in the weathering forms of the limestone. Limestone biological patina resulted from the higher porosity of Egyptian limestone, textural characteristics, and soluble and suspended aerosols in the groundwater. The deterioration products $(\mathrm{Cl}, \mathrm{Si}, \mathrm{Na}, \mathrm{S}$, and $\mathrm{Fe}$ ) and the essential element of limestone (Ca) rated $52 \%: 48 \%$. SEM and PM test showed that limestone in Qaitbay Mosque was exposed to aggressive weathering processes. Halite crystals existed as a major salt because it is the predominant salt in the Egyptian soil. Moreover, micro-cracks and cavities resulted from the textural characteristics of sedimentary rocks and the effect of deterioration processes. The XRD results illustrated that the weathering products on the limestone used in the Mosque varied according to the sampling location (inside or outside the building) and height on walls. The presence of Halite $\mathrm{NaCl}$, as a major mineral, highlighted the severe weathering processes of the limestone in the historical buildings of the Mamluks cemetery resulting from the chemical reaction between calcite and a combination of groundwater and sewage resulting from the lack of the infrastructure system. A partial consolidation should be carried out to the limestone that has aggressive deterioration phenomena due to weathering factors.

\section{References}

[1] Goudie, A. \& Viles, H. (1997), Salt weathering hazards, John Wiley \& Sons, New York

[2] Esponsa, M. \& Scherer, G. (2010), Mechanisms of damage by salt, in: Smith, B., Gomez-Hars, M., Viles, H. \& Cassar, J. (eds.) Limestone in the Built Environment: Present-Day Challenges for the Preservation of the Past, Special Pub., Vol. 331, Geological Society, London, pp: 61-77.

[3] Abdelmegeed, M., Badogiannis, E., Kotsovos, G. \& Vougioukas, E., (2014). Assessment of physical and mechanical properties of historical and traditional masonry buildings: A case study, IJCS, Vol. 5 (3), pp: 343-354

[4] Hendry, E., (2001). Masonry walls: Materials and constructions, Construction and Building Materials, Vol. 15 (8), pp: 323-330.

[5] Lilley D. \& March A., (1997). Problems in rubble-filled random masonry walls, Transaction on the Built Env- ironmental, Structural Studies, Repairs and Maintenance of Historical Buildings, Vol 26 (1997), pp: 417- 426.

[6] Abdelmegeed, M., (2015). Damage assessment and rehabilitation of historic traditional masonry structures, $\mathrm{PhD}$, School of Civil Engineering, dept. of Structural Engineering, Metsovo Polytechnic, NTUA, Athens, Greece

[7]El-Akkad, T., (2013). The aesthetics of Islamic architecture of Mamluk design, $\mathrm{PhD}$, Catalonia Univ., Barcelona, España.

[8] Flatt, R., (2002). Salt damage in porous materials: How high super-saturations are generated, J. of Crystal Growth, Vol. 242 (3-4), pp: 435-454 .

[9] Coussy, O., (2006), Deformation and stress from in-pore drying-induced crystallization of salt, J. of the Mechanics \& Physics of Solids, Vol. 54, pp: 1517-1547.

[10] El-Gohary, M., (2010), Investigations of limestone weathering of El-tuba 
minaret El-Mehala, Egypt: a case study, MAA, Vol. 10 (1), pp: 61-79.

[11] Fitzner, B. (2002). Damage diagnosis on stone monuments-weathering forms, damage categories and damage indices, in: Viles, H. \& Přikryl, R., (eds.) Und-erstanding and managing of stone decay, Proc. of the Int. Conf. Stone Weathering and Atmospheric Pollution Network (SWAPNET 2001), Karolinum Press, Charles Univ., Prague, pp: 11-56.

[12] Espinosa, M. \& Scherer, G., (2009). Crystallization pressure exerted by in-pore confined crystals, in poromechanics IV, in: Ling, H., Smyth, A. $\&$ Betti, R. (eds.) Proc. Fourth Biot Conf. on Poromechanics, DEStech Pub., Lancaster, PA NY, pp; 10131018.

[13] Cherblanc F., Bromblet, P. \& Berthonneau, J., (2016). Role of hydromechanical coupling in the damage process of limestone used in historical buildings, in: Hughes, J. \& Torsten, H. (eds.) $13^{\text {th }}$ Int. Cong. on the Deterioration and Conservation of Stone, Vol. I, Univ. of the West of Scotland, Paisley, Scotland, pp: 49-56.

[14] Cassar G., (2010). The use of limestone in a historic context: The experience of Malta, in: Smith, B., GomezHars, M., Viles, H. \& Cassar, J. (eds.) Limestone in the Built Environment: Present-Day Challenges for the Preservation of the Past, Special Pub., Vol. 331, Geological Society, London, pp: $13-25$

[15] Dunham, R., (1962). Classification of carbonate rocks according to depositional textures, classification of carbonate rocks, in: Ham, W. (ed.) American Association Petroleum Geologists, Vol. 1, pp:108:121

[16] Maekawa V. \& Agnew N., (1996). Investigation of environmentally driven deterioration of the great sphinx and concepts for protection, Archaeological conservation and its consequences, Studies in Conservation, Vol. 41 (Sup. 1), pp: 116-120
[17] Esponsa M., Scherer G., (2010). Mech-anisms of damage by saltin: Smith, B., Gomez-Hars, M., Viles, H. \& Cassar, J. (eds.) Limestone in the Built Environment: Present-Day Challenges for the Preservation of the Past, Special Pub., Vol. 331, Geological Society, London, pp: 61-77

[18] Abdelmonem M. (2012). The practice of home in old Cairo: Towards sociospatial models of sustainable living, Traditional Dwellings and Settlement Review, Vol. 23 (2), pp: 35-50.

[19] Sutton, K. \& Fahmi, W., (2002). Cairo's "cities of the dead": The myths, problems, and future of a unique squatter Settlement, The Arab World Geographer, Vol. 5 (1), pp: 1-21.

[20] UNESCO., (2012). Urban regeneration project for historic Cairo: Management of world heritage sites in Egypt, Urban Regeneration Project for Historic Cairo, $1^{\text {st }}$ Report 20102012, UNESCO World Heritage Centre, UNESCO, Egypt.

[21] Cipriani, p., (2005). Development of construction techniques in the Mamluks domes of Cairo, MA, Architecture and Urban Planning dept., Istituto Universitario di architettura di Venezia, Italy.

[22] ICOMOS Charter (2003). Principles for the analysis, conservation and structural restoration of architectural heritage, Ratified by ICOMOS $14^{\text {th }}$ General Assembly in Victoria Falls, Zimbabwe.

[23] Shahrbanoo G., da Costa, C., (2018). An empirical investigation of architectural heritage management implications for tourism: The case of Portugal, Sustainability, Vol. 10 (93), pp: 1-32

[24] Siravo, F., (2001). Reversing the decline of a historic district: Aga Khan historic cities programme, Cairo, Egypt, https://archnet.org/pu blications $/ 3388$

[25] Matteoli, U., Manganelli del fa, C., Frediani, P., Tiano, P. \& Piacenti, F., (1981). Humidity in stones - II: 
Humidity and temperature determinations in various lithotypes, in: Centro per la conservazione delle sculture all'aperto (ed.) Int. Symp. Humidity in Stones - II, Bologna, pp: 475-481

[26] El-Gohary, M., (2016). A holistic approach to the assessment of the groundwater destructive effects on stone decay in Edfu temple using AAS, SEM-EDX and XRD, Environ. Earth. Sci., Vol. 75 (13), pp: 1-11

[27] Livingston, R., (1988). The application of petrology to the predication of stone durability, in: Ciabach. J. (ed.) VI $I^{\text {th }}$ Int. Cong. on Deterioration and Conservation of Stone, Nicholas Copernicus Univ. Press, Toruń, pp: 432-445.

[28] Liritzis, I., (2001), Searching for precision of a new 'luminescence clock' in dating calcitic rocks. $J$. Radioanal. \& Nucl. Chemistry, 247 (3), pp: 727-730.

[29] Liritzis, .I, Guibert, P., Foti, F. \& Schvoerer, M., (1997). The Temple of Apollo (Delphi) strengthens new thermoluminescence dating method. Geoarchaeology Int., Vol. 12 (5), pp: 479-496.

[30] Kühlenthal, M. \& Fischer, H., (2000). Guidelines and procedures for the restoration of the monuments in Petra, in: Kühlenthal, M. \& Fischer, H. (eds.) The Restoration of the Rockcut Tomb Facades, Shefte des Bayerischen Landesamtes für Denkmalpflege, München, pp:84-86.

[31] Fitzner, B., Heinrichs, K. \& Kownatzki, R., (1995). Weathering forms at natural stones monuments - classification, mapping and evaluation. Int. J. for Restoration of Buildings and Monuments, Vol. 3 (2), pp: 105124 .

[32] Derluyn, H., Boone, M., Desarnaud, J. \& Grementieri, L., (2016). Quantifying salt crystallization dynamics in sandstone using 4D laboratory X-ray micro-ct, in: Hughes, J. \& Torsten, H. (eds.) $13^{\text {th }}$ Int. Cong. on the Deterioration and Conservation of Stone, Vol. I, Univ. of the West of Scotland, Paisley, Scotland, pp: 8390.

[33] Fitzner, B., Heinrichs, K., \& La Bouchardiere, D., (2006). Limestone weathering on historical monuments in Cairo, Egypt, Special Pub., Geological Society, London, Vol. 205, pp: 217-239

[34] El-Gohary, M., (2008). Air pollution and aspects of degradation "Umayyad Liwãn-Amman citadel as a case study", Int. J. of Applied Sciences Research, Vol. 4 (6), pp: 669-682

[35] El-Gohary, M. \& Redwan, M., (2018). Alteration parameters affecting the Luxor Avnuxe of the Sphinxes-Egypt, STOTEN, Vol. 626, pp: 710-719

[36] El-Gohary, M., (2017). Environmental impacts: Weathering factors, mechanism and forms affected the stone decaying in Petra, African Earth Sciences, Vol. 135, pp: 204-212

[37] El-Gohary, M., (2015). Effective roles of some deterioration agents affecting Edfu royal Birth House "Mammisi", IJCS, Vol. 6 (3), pp: 349-368

[38] Ali, M., Alenbaawy, M. \& Moussa, A., (2011). Characteristics of building materials exposed to geoenvironmental impacts in Makaad Radwan, Ottoman Cairo, Egypt, EJARS, Vol. 1 (2), pp: 41-51 